Available online on 15.02.2020 at http://jddtonline.info
Open Access to Pharmaceutical and Medical Research
unrestricted non-commercial use, provided the original work is properly cited

Open 2 Access

Research Article

\title{
Antioxidant and Antibacterial Activities of ethanol fruit extract of Cherry Plum - Prunus cerasifera Ehrh.
}

\author{
Saraswathi $\mathrm{K}^{1}$, Sivaraj $\mathrm{C}^{2}$, Arumugam $\mathrm{P}^{2 *}$ \\ ${ }^{1}$ Department of Biotechnology, Karpaga Vinayaga College of Engineering and Technology, Madhuranthagam, Kancheepuram - 603308 \\ ${ }^{2}$ ARMATS Biotek Training and Research Institute, Guindy, Chennai-600 032
}

\begin{abstract}
Foods that have disease-preventing potential are designated as functional foods. Functional foods are foods that provide health benefits beyond basic nutrition. A large number of antioxidants, both nutritive and nonnutritive, occur in foods. The potency of antioxidants present in foods in vivo will depend not only on their levels in the foods but also on their bioavailability, that is, the extent to which the active forms of antioxidants are released from the food and absorbed through the gut. Most of phytochemicals, components of food, beverages, and herbal products are often reported in literature as "nutraceutical", emphasizing their health promoting properties, including the prevention and treatment of pathologies like cancer, cardiovascular diseases, neural disorders, and Alzheimer's disease. Phytochemicals are virtually present in all the fruits, vegetables, pulses/legumes and grains which are commonly consumed, so it is quite easy to incorporate them in our daily diet. Current research studies were carried out for evaluating the antioxidant and antibacterial activities of ripe fruits of ethanol extract of Prunus cerasifera Antioxidant activities such as $\mathrm{DPPH}^{-}$radical, Superoxide $\left(\mathrm{O}_{2}{ }^{-}\right)$radical, $\mathrm{ABTS}^{\bullet+}$ radical cation, phosphomolybdenum reduction and Fe ${ }^{3+}$ reduction were carried out for ripe fruits of ethanol extract of Prunus cerasifera. The maximum $\mathrm{DPPH}^{*}$ radical and Superoxide $\left(\mathrm{O}_{2}{ }^{-}\right)$radical scavenging activities were $82.11 \pm 0.42 \%$ and $46.26 \pm 0.28 \%$ at $120 \mu \mathrm{g} / \mathrm{mL}$ concentration and the $\mathrm{IC}_{50}$ values were $45.40 \mu \mathrm{g} / \mathrm{mL}$ and $129.70 \mu \mathrm{g} / \mathrm{mL}$ concentrations respectively. The maximum ABTS ${ }^{\bullet}$ radical cation scavenging activity was $88.64 \pm 0.43 \%$ at $30 \mu \mathrm{g} / \mathrm{mL}$ concentration and the $\mathrm{IC}_{50}$ value was $10.09 \mu \mathrm{g} / \mathrm{mL}$ concentration respectively. The maximum $\mathrm{Mo}^{6+}$ reduction and $\mathrm{Fe}^{3+}$ reduction were $86.29 \pm 0.29 \%$ and $79.82 \pm 0.20 \%$ at $120 \mu \mathrm{g} / \mathrm{mL}$ concentration and the $\mathrm{RC}_{50}$ values were $20.45 \mu \mathrm{g} / \mathrm{mL}$ and $24.21 \mu \mathrm{g} / \mathrm{mL}$ concentrations respectively. The antibacterial activity of ripe fruits of ethanol extract of Prunus cerasifera showed maximum zone of inhibition of $20 \mathrm{~mm}$ for Bacillus subtilis at $500 \mu \mathrm{g} / \mathrm{mL}$ concentration.
\end{abstract}

Keywords: Antioxidant, Superoxide $\left(\mathrm{O}_{2 \cdot-}\right)$ radical, ABTS $\bullet+$ radical cation, $\mathrm{Fe}^{3+}$ reduction and phenolic compounds.

Article Info: Received 19 Nov 2019; $\quad$ Review Completed 12 Jan 2020; $\quad$ Accepted 21 Jan 2020; Available online 15 Feb 2020

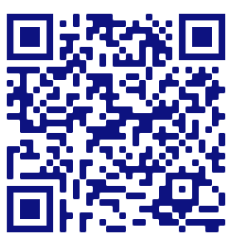

Cite this article as:

Saraswathi K, Sivaraj C, Arumugam P, Antioxidant and Antibacterial Activities of ethanol fruit extract of Cherry Plum Prunus cerasifera Ehrh., Journal of Drug Delivery and Therapeutics. 2020; 10(1-s):45-50 http://dx.doi.org/10.22270/jddt.v10i1-s.3851

Dr. P. Arumugam, Industrial Fermentation Technology Division, ARMATS Biotek Training and Research Institute, Chennai - 600 032, Tamil Nadu, India

\section{INTRODUCTION}

Plums are one of the most important stone fruits crops of the world. Plums also include several familiar stone fruitsapricot,cherry and peach. Plums are important source of compounds influencing human health and preventing the occurrence of many diseases ${ }^{1,2}$. Plums have high sugar content, so to maintain the nutritional and sensory quality, dehydration to desired moisture content, sub atmospheric conditions are desirable ${ }^{3}$. Plums are a drupe fruit of the subgenus Prunus of the genus Prunus. They come in a wide variety of size and colours like yellow, white, green or red flesh (Figure 1). Mature plum fruit may have a dusty-white coating that gives them a glaucous appearance 4 . Plums have low calorie relatively high nutritive value. They contain carbohydrates such as sucrose, glucose and fructose, followed by organic acids such as citric acid, malic acid, tannins, aromatic substances, minerals and enzymes ${ }^{5}$. Major phenolic compounds in plum fruits are derivatives of caffeic acid: 3-0-caffeicquinic (neochlorogenic acid), 5-0caffeicquinic (chlorogenic acid) and 4-0- caffeicquinic (cryptochlorogenic acid) as well as caffeic acid, together with smaller amounts of anthocyanins, flavonols 6 .

Free radicals attack three main cellular components.

Lipids - Peroxidation of lipids in cell membranes can damage cell membranes by disrupting fluidity and permeability. Lipid peroxidation can also adversely affect the function of membrane bound proteins such as enzymes and receptors.

Proteins - Direct damage to proteins can be caused by free radicals. This can affect many kinds of protein, interfering 
with enzyme activity and the function of structural proteins. DNA - Fragmentation of DNA caused by free radical attack causes activation of the poly (ADP-ribose) synthetase enzyme. This splits NAD+ to aid the repair of DNA. However, if the damage is extensive, $\mathrm{NAD}^{+}$levels may become depleted to the extent that the cell may no longer be able to function and dies. The site of tissue damage by free radicals is dependent on the tissue and the reactive species involved. Extensive damage can lead to death of the cell; this may be by necrosis or apoptosis depending on the type of cellular damage. When a cell membrane or an organelle membrane is damaged by free radicals, it loses its protective properties. This puts the health of the entire cell at risk ${ }^{7}$.

\section{Taxonomic Classification of Prunus cerasifera}

Kingdom: Plantae

Clade: Tracheophytes

Family: Rosaceae

Genus: Prunus

Species: cerasifera

Binomial name: Prunus cerasifera Ehrh.

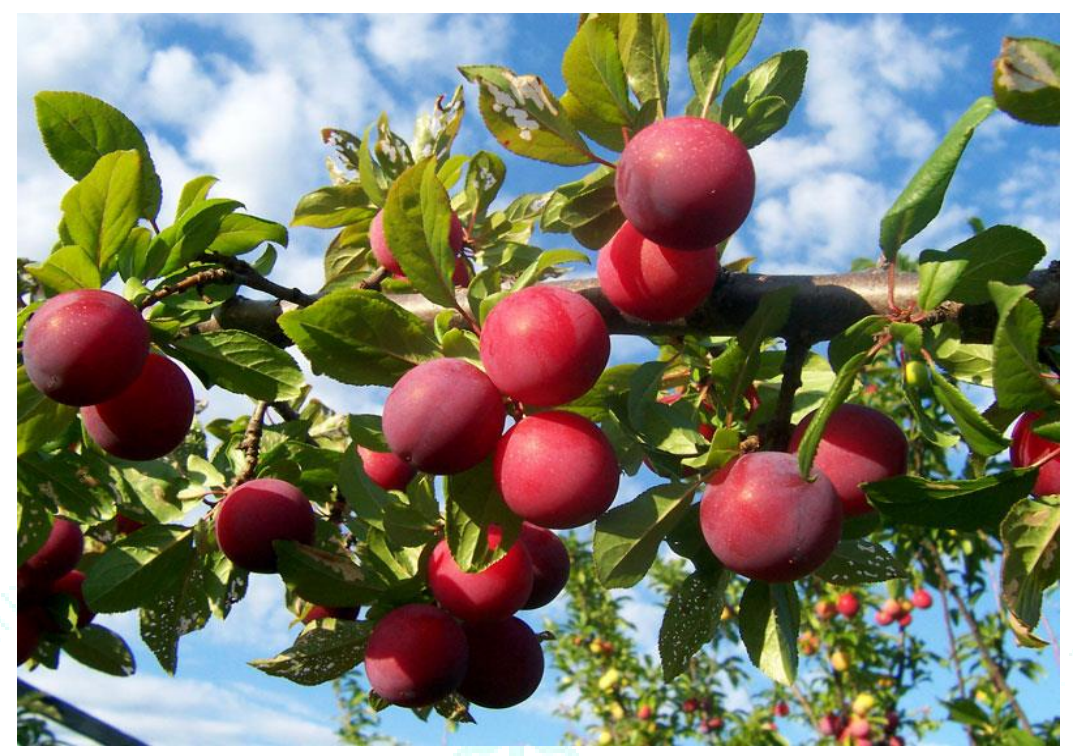

Figure.1: Habitat of Prunus cerasifera

\section{MATERIALS AND METHODS}

\section{Collection and Extraction process of ripe fruits of Prunus cerasifera}

The ripe fruits of Prunus cerasifera were collected from the market at Maduvinkarai, Chennai, Tamil Nadu, India. The ripe fruits of Prunus cerasifera were made into fine pieces and soaked in ethanol for 72 hours. The intense red coloured supernatant was filtered, condensed in a hot plate at $50^{\circ} \mathrm{C}$, which yields red viscous extract ${ }^{8,9}$.

\section{In vitro antioxidant activities}

\section{DPPH" radical scavenging activity}

The radical scavenging activity of ripe fruits of Prunus cerasifera was carried out by the reduction $\mathrm{DPPH} \cdot$ free radical method ${ }^{10}$. One $\mathrm{mL}$ of ripe fruits of ethanol extract of Prunus cerasifera with various concentrations (20-120 $\mu \mathrm{g} / \mathrm{mL}$ ) was mixed with $1 \mathrm{~mL}$ of $0.1 \mathrm{mM}$ DPPH solution in methanol. The mixture was then allowed to stand for $30 \mathrm{~min}$ incubation in dark. One $\mathrm{mL}$ of methanol mixed with $1 \mathrm{~mL}$ of DPPH solution was used as the control. The decrease in absorbance was measured at $517 \mathrm{~nm}$ using UV-Vis spectrophotometer. Ascorbic acid was used as the standard reference. The percentage of inhibition was calculated as:

$$
\% \text { of } \mathrm{DPPH}^{*} \text { radical inhibition }=\frac{\text { Control }- \text { Sample }}{\text { Control }} \times 100
$$

\section{Superoxide $\left.\left(\mathrm{O}_{2}-\right)^{-}\right)$radical scavenging activity}

Superoxide $\left(\mathrm{O}_{2}-\mathrm{-}\right)$ radical scavenging activity was carried out by the method ${ }^{11}$ and the reaction mixture contains different concentrations $(20-120 \mu \mathrm{g} / \mathrm{mL})$ of ripe fruits of ethanol extract of Prunus cerasifera with $50 \mathrm{mM}$ of phosphate buffer (pH 7.4), $200 \mu \mathrm{L}$ of $1.5 \mathrm{mM}$ of riboflavin, $200 \mu \mathrm{L} 12 \mathrm{mM}$ of EDTA and $100 \mu \mathrm{L} 50 \mathrm{mM}$ of NBT, added in that sequence. The reaction was started by illuminating the reaction mixture for 15 min in UV lamp. After illumination, the absorbance was measured at $590 \mathrm{~nm}$ using UV-Vis spectrophotometer. Ascorbic acid was used as the standard reference. The percentage of inhibition was calculated as:

$\%$ of Superoxide (O2. -) radical inhibition $=\frac{\text { Control }- \text { Sample }}{\text { Control }} \times 100$

ABTS•+ (2,2-azinobis (3-ethylbenzo thiazoline-6-sulfonic acid) radical cation scavenging activity

The ripe fruits of ethanol extract of Prunus cerasifera from the stock solution was taken in various concentrations and this assay was performed according to the method ${ }^{12}$. The stock solutions included 7.4 mM ABTS solution and $2.6 \mathrm{mM}$ potassium persulfate solution. The working solution was then prepared by mixing the two stock solutions in equal quantities and allowing them to react for 12 hours at room temperature in the dark. Fresh ABTS solution was prepared for each experiment. The ripe fruits of ethanol extract of Prunus cerasifera in varying concentrations $(5-30 \mu \mathrm{g} / \mathrm{mL})$ were allowed to react with $500 \mu \mathrm{L}$ of the ABTS solution for 15 minutes in dark condition and the absorbance was measured at $734 \mathrm{~nm}$ using UV-Vis spectrophotometer. Ascorbic acid was used as the standard reference. The percentage of inhibition was calculated as:

$$
\% \text { of ABTS } \bullet+\text { radical cation inhibition }=\frac{\text { Control }- \text { Sample }}{\text { Control }} \times 100
$$




\section{Phosphomolybdenum reduction activity}

The antioxidant capacity of the ripe fruits of ethanol extract of Prunus cerasifera was assessed as described ${ }^{13}$. The ripe fruits of ethanol extract of Prunus cerasifera with varying concentrations ranging $(20-120 \mu \mathrm{g} / \mathrm{mL})$ was combined with reagent solution containing ammonium molybdate $(4 \mathrm{mM})$, sodium phosphate $(28 \mathrm{mM})$ and sulphuric acid $(600 \mathrm{mM})$. The reaction mixture was incubated in water bath at $95^{\circ} \mathrm{C}$ for $90 \mathrm{~min}$. The absorbance of the coloured complex was measured at $695 \mathrm{~nm}$ using UV-Vis spectrophotometer. Ascorbic acid was used as the standard reference. The percentage of reduction was calculated as:

$$
\% \text { of Phosphomolybdenum reduction }=\frac{\text { Sample }- \text { Control }}{\text { Sample }} \times 100
$$

\section{Ferric $\left(\mathrm{Fe}^{3+}\right)$ reducing power activity}

The reducing power of ripe fruits of ethanol extract of Prunus cerasifera was determined by slightly modified method $^{14}$. One $\mathrm{mL}$ of ripe fruits of ethanol extract of Prunus cerasifera of different concentrations $(20-120 \mu \mathrm{g} / \mathrm{mL})$ was mixed with phosphate buffer $(1 \mathrm{~mL}, 0.2 \mathrm{M}, \mathrm{pH}$ 6.6) and potassium ferricyanide $\left[\mathrm{K}_{3} \mathrm{Fe}(\mathrm{CN})_{6}\right](1 \mathrm{~mL}, 1 \% \mathrm{w} / \mathrm{v})$. The mixtures were then incubated at $50^{\circ} \mathrm{C}$ for $20 \mathrm{~min}$ in water bath. $500 \mu \mathrm{L}$ of trichloroacetic acid $(10 \% \mathrm{w} / \mathrm{v})$ was added to each mixture, followed by $100 \mu \mathrm{L}$ of Ferric chloride $(0.01 \%$, $\mathrm{w} / \mathrm{v}$ ) was added and the absorbance was measured at 700 nm using UV-Vis spectrophotometer. Ascorbic acid was used as the standard reference. The percentage of reduction was calculated as:

$$
\% \text { of } \mathrm{Fe}^{3+} \text { reduction }=\frac{\text { Sample }- \text { Control }}{\text { Sample }} \times 100
$$

\section{Determination of total phenols}

Folin-Ciocalteau reagent method was used to determine the total phenolic compounds ${ }^{15}$ with slight modifications. One hundred $\mu \mathrm{L}$ of ripe fruits of ethanol extract of Prunus cerasifera $(1 \mathrm{mg} / \mathrm{mL})$ was mixed with $900 \mu \mathrm{L}$ of methanol and $1 \mathrm{~mL}$ of Folin Ciocalteau reagent (1:10 diluted with distilled water). After $5 \mathrm{~min}, 1 \mathrm{~mL}$ of $\mathrm{Na}_{2} \mathrm{CO}_{3}(20 \% \mathrm{w} / \mathrm{v})$ was added. The mixture was then allowed to stand for $30 \mathrm{~min}$ incubation in dark at room temperature. The absorbance was measured using UV-Vis spectrophotometer at $765 \mathrm{~nm}$. The total phenolic content was expressed in terms of gallic acid equivalent ( $\mu \mathrm{g} / \mathrm{mg}$ of extract), which is a common reference compound.

\section{Determination of total flavonoids}

The total flavonoid content of ripe fruits of ethanol extract of Prunus cerasifera was determined using aluminium chloride colorimetric method with slight modification as described 16 . $500 \mu \mathrm{L}$ of ripe fruits of ethanol extract of Prunus cerasifera $(1$ $\mathrm{mg} / \mathrm{mL}$ ) was mixed with $500 \mu \mathrm{L}$ of methanol, $0.5 \mathrm{~mL}$ of $5 \%$ (w/v) sodium nitrite solution and incubated for $5 \mathrm{~min}$ at room temperature. Then, $0.5 \mathrm{~mL}$ of $10 \%(\mathrm{w} / \mathrm{v})$ aluminium chloride solution was added and incubated for further $5 \mathrm{~min}$ at room temperature followed by addition of $100 \mu \mathrm{L}$ of $1 \mathrm{M}$ $\mathrm{NaOH}$ solution. The total volume was made up to $2 \mathrm{~mL}$ with distilled water. The absorbance was measured at $510 \mathrm{~nm}$ using UV-Vis spectrophotometer. The total flavonoid content was expressed in terms of quercetin equivalent $(\mu \mathrm{g} / \mathrm{mg}$ of extract), which is a common reference compound.

\section{Antibacterial activity by Agar well diffusion method}

Nutrient agar was prepared and poured in the sterile Petri dishes and allowed to solidify. 24 hours grown bacterial pathogens were swabbed on nutrient agar plates ${ }^{17}$. Then, the ripe fruits of ethanol extract of Prunus cerasifera in varying concentrations $(250 \mu \mathrm{g} / \mathrm{mL}, 375 \mu \mathrm{g} / \mathrm{mL}$ and $500 \mu \mathrm{g} / \mathrm{mL})$ was loaded in the clean lawns made using sterile cork borer. Tetracycline $(30 \mu \mathrm{g})$ was used as standard. The plates were then incubated at $37^{\circ} \mathrm{C}$ for 24 hours and after incubation, the inhibition diameter was measured and recorded.

\section{RESULTS AND DISCUSSION}

\section{DPPH' radical and Superoxide $\left(\mathrm{O}_{2}-{ }^{-}\right)$radical scavenging activities of ripe fruits of ethanol extract of Prunus cerasifera}

Evaluation of antioxidant activity by DPPH method is the best screening option for herbal based drugs. DPPH ${ }^{*}(1,1-$ Diphenyl-2-picrylhydrazyl) is a stable nitrogen centered free radical which has an unpaired valence electron at one atom of nitrogen bridge ${ }^{18}$. The ability of ripe fruits of ethanol extract of Prunus cerasifera to scavenge free radicals formed was assessed using 1,1-diphenyl-2-picryl hydrazyl radical (DPPH). The ripe fruits of ethanol extract of Prunus cerasifera demonstrated high capacity for scavenging free radicals by reducing the stable DPPH (1,1-diphenyl-2- picryl hydrazyl) radical to the yellow coloured 1,1-diphenyl-2picryl hydrazine and the reducing capacity increased with increasing concentration of the extract. The maximum $\mathrm{DPPH}^{\circ}$ radical scavenging activity of ripe fruits of ethanol extract of Prunus cerasifera was $82.11 \pm 0.42 \%$ at $120 \mu \mathrm{g} / \mathrm{mL}$ concentration (Table 1). The $\mathrm{IC}_{50}$ value for the ripe fruits of ethanol extract of Prunus cerasifera was found to be 45.40 $\mu \mathrm{g} / \mathrm{mL}$ concentration respectively (Graph 1) and was compared with standard (Ascorbic acid, $\mathrm{IC}_{50}=13.86 \mu \mathrm{g} / \mathrm{mL}$ concentration).

Superoxide anion is also very harmful to cellular components and their effects can be magnified because it produces other kinds of free radicals and oxidizing agents. Flavonoids are effective antioxidants, mainly because they scavenge superoxide anions. Superoxide anions derived from dissolved oxygen by the riboflavin-light-NBT system will reduce NBT in this system. In this method, superoxide anion reduces the yellow dye $\left(\mathrm{NBT}^{2+}\right)$ to blue formazan, which is measured at $590 \mathrm{~nm}$ using UV-Vis spectrophotometer. Antioxidants are able to inhibit the blue NBT formation and the decrease of absorbance with antioxidants indicates the consumption of superoxide anion in the reaction mixture ${ }^{19}$. The maximum superoxide $\left(\mathrm{O}_{2}-\right.$ - $)$ radical scavenging activity of ripe fruits of ethanol extract of Prunus cerasifera was $46.26 \pm 0.28 \%$ at $120 \mu \mathrm{g} / \mathrm{mL}$ concentration (Table 1 and Graph 1) and the $\mathrm{IC}_{50}$ value for the ripe fruits of ethanol extract of Prunus cerasifera was found to be $129.70 \mu \mathrm{g} / \mathrm{mL}$ concentration respectively. It was compared with the standard of ascorbic acid $\left(\mathrm{IC}_{50}=14.63\right.$ $\mu \mathrm{g} / \mathrm{mL}$ concentration). 
Table 1: $\mathrm{DPPH}^{*}$ radical and Superoxide $\left(\mathrm{O}_{2--}\right)$ radical scavenging activities of ripe fruits of ethanol extract of Prunus cerasifera

\begin{tabular}{|c|c|c|c|}
\hline S.No & $\begin{array}{c}\text { Concentration } \\
(\boldsymbol{\mu g} / \mathbf{m L})\end{array}$ & \multicolumn{2}{|c|}{ \% of inhibition* } \\
\cline { 3 - 4 } & & $\begin{array}{c}\text { DPPH } \\
\text { radical }\end{array}$ & $\begin{array}{c}\text { Superoxide } \\
\left(\mathbf{O}_{2}-\mathbf{-}\right) \text { radical }\end{array}$ \\
\hline 1 & 20 & $38.49 \pm 0.21$ & $12.28 \pm 0.25$ \\
\hline 2 & 40 & $44.05 \pm 0.26$ & $29.84 \pm 0.16$ \\
\hline 3 & 60 & $53.67 \pm 0.34$ & $32.02 \pm 0.29$ \\
\hline 4 & 80 & $69.32 \pm 0.46$ & $33.98 \pm 0.33$ \\
\hline 5 & 100 & $78.29 \pm 0.15$ & $39.50 \pm 0.48$ \\
\hline 6 & 120 & $82.11 \pm 0.42$ & $46.26 \pm 0.28$ \\
\hline
\end{tabular}

(*Average value of 3 replicates)

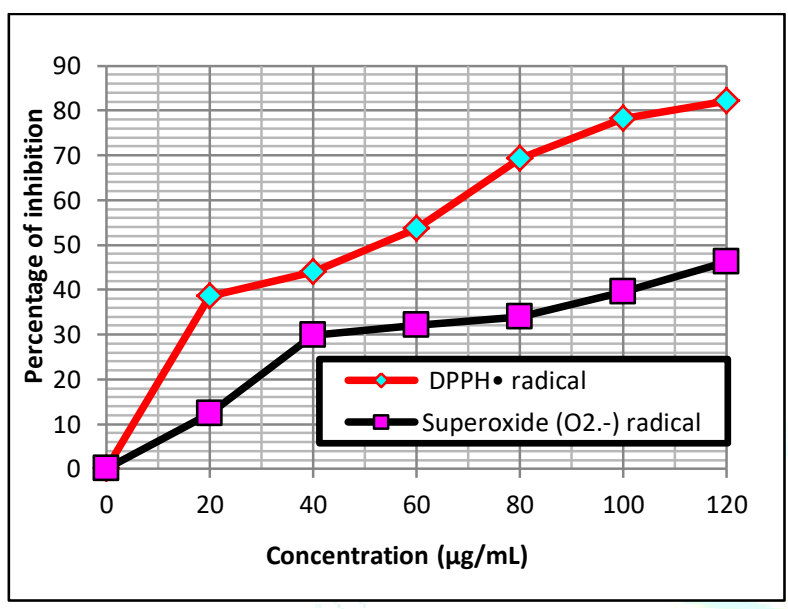

Graph 1: $\mathrm{DPPH}^{*}$ radical and Superoxide $\left(\mathrm{O}_{2}-\mathrm{-}\right)$ radical scavenging activities of ripe fruits of ethanol extract of Prunus cerasifera

ABTS $^{\bullet+}$ radical cation scavenging activity of ripe fruits of ethanol extract of Prunus cerasifera

ABTS ${ }^{-+}$is a blue chromophore produced by the reaction between ABTS and potassium persulfate and ABTS ${ }^{\bullet+}$ radical cation gets reduced in the presence of ripe fruits of ethanol extract of Prunus cerasifera and the remaining radical cation concentration was then quantified at $734 \mathrm{~nm}$. It can be prepared using $\mathrm{K}_{2} \mathrm{~S}_{2} \mathrm{O}_{8}$ as an oxidant. The blue-green colour of ABTS solution is formed by the loss of an electron by the nitrogen atom of ABTS (2, 2-azinobis (3ethylbenzothiazolin6-sulfonic acid)). The decolourization of the solution takes place in the presence of hydrogen donating antioxidant (nitrogen atom quenches the hydrogen atom ${ }^{20}$. The maximum ABTS•+ radical cation scavenging activity of ripe fruits of ethanol extract of Prunus cerasifera was $88.64 \pm 0.43 \%$ at $30 \mu \mathrm{g} / \mathrm{mL}$ concentration (Table 2 and Graph 2) and the $\mathrm{IC}_{50}$ value for the ripe fruits of ethanol extract of Prunus cerasifera was found to be as $10.09 \mu \mathrm{g} / \mathrm{mL}$ concentration respectively, which was compared with standard ascorbic acid ( $\mathrm{IC}_{50}=4.75 \mu \mathrm{g} / \mathrm{mL}$ concentration).

Table 2: ABTS ${ }^{\bullet+}$ radical cation scavenging activity of ripe fruits of ethanol extract of Prunus cerasifera

\begin{tabular}{|c|c|c|}
\hline S.No & $\begin{array}{c}\text { Concentration } \\
(\boldsymbol{\mu g} / \mathbf{m L})\end{array}$ & \% of inhibition* \\
\cline { 3 - 3 } & & ABTS•+ radical cation \\
\hline 1 & 5 & $35.17 \pm 0.14$ \\
\hline 2 & 10 & $49.52 \pm 0.27$ \\
\hline 3 & 15 & $63.05 \pm 0.38$ \\
\hline 4 & 20 & $77.21 \pm 0.11$ \\
\hline 5 & 25 & $83.15 \pm 0.19$ \\
\hline 6 & 30 & $88.64 \pm 0.43$ \\
\hline
\end{tabular}

(*Average value of 3 replicates)

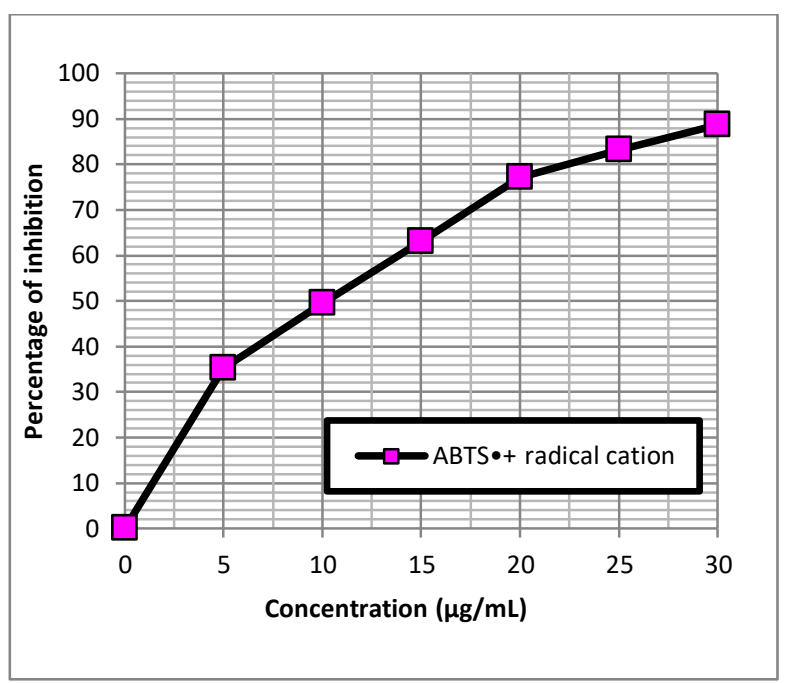

Graph 2: ABTS •+ radical cation scavenging activity of ripe fruits of ethanol extract of Prunus cerasifera

Phosphomolybdenum reduction and Ferric $\left(\mathrm{Fe}^{3+}\right)$ reducing power activities of ripe fruits of ethanol extract of Prunus cerasifera

The total antioxidant activity of ripe fruits of ethanol extract of Prunus cerasifera was measured spectrophotometrically by phosphomolybdenum reduction method, which is based on the reduction of Mo (VI) to Mo (V) by the formation of green phosphate/Mo (V) complex at acidic $\mathrm{pH}$, with a maximum absorption at $695 \mathrm{~nm}^{21}$. The maximum phosphomolybdenum reduction of ripe fruits of ethanol extract of Prunus cerasifera was $86.29 \pm 0.29 \%$ at $120 \mu \mathrm{g} / \mathrm{mL}$ concentration with the $\mathrm{RC}_{50}$ value of $20.45 \mu \mathrm{g} / \mathrm{mL}$ concentration respectively (Table 3 and Graph 3). It was compared with the standard ascorbic acid $\left(\mathrm{RC}_{50}=8.16\right.$ $\mu \mathrm{g} / \mathrm{mL})$.

The reducing power of $\mathrm{Fe}^{3+}$ to $\mathrm{Fe}^{2+}$ by ripe fruits of ethanol extract of Prunus cerasifera was studied and showed reduction ability in a dose dependent manner. The maximum reduction of ripe fruits of ethanol extract of Prunus cerasifera was $79.82 \pm 0.20 \%$ at $120 \mu \mathrm{g} / \mathrm{mL}$ concentration (Table 3 and Graph 3). Fe (III) reduction is often used as an indicator of electron donating activity, which is an important mechanism of phenolic antioxidant action ${ }^{22}$. The $\mathrm{RC}_{50}$ value for the ripe fruits of ethanol extract of Prunus cerasifera as found to be $24.21 \mu \mathrm{g} / \mathrm{mL}$ concentration respectively and was compared with the standard (22.73 $\mu \mathrm{g} / \mathrm{mL}$ concentration) Ascorbic acid.

Table 3: Phosphomolybdenum reduction and Ferric $\left(\mathrm{Fe}^{3+}\right)$ reducing power activities of ripe fruits of ethanol extract of Prunus cerasifera

\begin{tabular}{|c|c|c|c|}
\hline S.No & $\begin{array}{c}\text { Concentration } \\
(\boldsymbol{\mu g} / \mathbf{m L})\end{array}$ & \multicolumn{2}{|c|}{ \% of reduction* } \\
\cline { 3 - 4 } & & $\begin{array}{c}\mathbf{M o}^{\mathbf{+}} \\
\text { reduction }\end{array}$ & $\begin{array}{c}\mathbf{F e}^{3+} \\
\text { reduction }\end{array}$ \\
\hline 1 & 20 & $48.88 \pm 0.33$ & $41.29 \pm 0.41$ \\
\hline 2 & 40 & $55.37 \pm 0.12$ & $58.91 \pm 0.22$ \\
\hline 3 & 60 & $78.64 \pm 0.26$ & $74.63 \pm 0.47$ \\
\hline 4 & 80 & $82.07 \pm 0.45$ & $75.38 \pm 0.19$ \\
\hline 5 & 100 & $84.16 \pm 0.10$ & $76.03 \pm 0.39$ \\
\hline 6 & 120 & $86.29 \pm 0.29$ & $79.82 \pm 0.20$ \\
\hline
\end{tabular}

(*Average value of 3 replicates) 


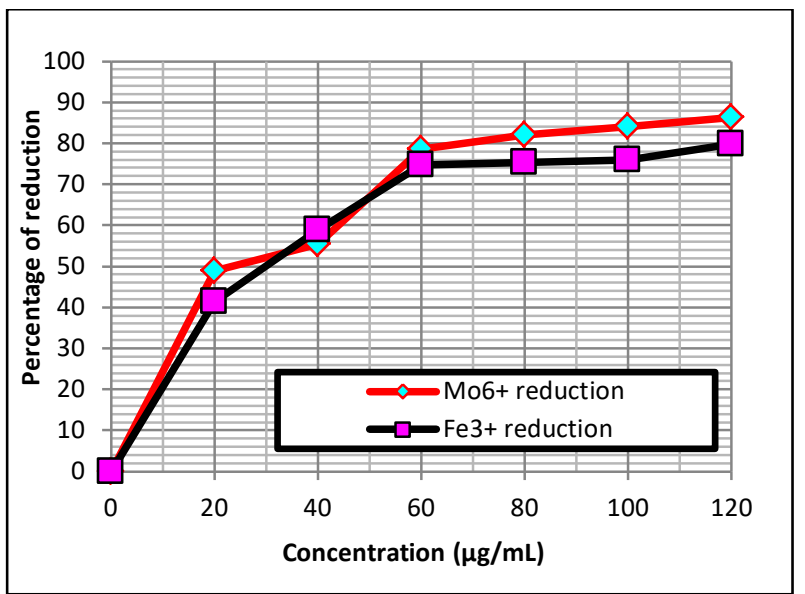

Graph 3: Phosphomolybdenum reduction and Ferric $\left(\mathrm{Fe}^{3+}\right)$ reducing power activities of ripe fruits of ethanol extract of Prunus cerasifera

\section{Determination of total phenols and flavonoids}

Flavonoids and phenolics acids are the most important bioactive natural product of secondary metabolites and act as an antioxidant and anti-aging substances, capable of scavenging free radicals and reducing the risk of cancer ${ }^{23}$. Oxidative stress is a harmful condition that occurs when there is an excess of ROS and decrease in antioxidant levels and cause tissue damage which leads to different diseases. Flavonoids and phenolic compounds are well known for their antioxidant activity that protect humans against the damaging effects of free radicals in addition an imbalance between antioxidants and free radicals results in oxidative stress, will lead to cellular damage. Phenolic hydroxyl groups are good hydrogen donors, which are hydrogen-donating antioxidants can react with reactive oxygen species and reactive nitrogen species which breaks down the generation of new radicals in a termination reaction. Phenolic structures often have the potential to interact strongly with proteins, due to their hydrophobic benzenoid rings and hydrogen-bonding potential of the phenolic hydroxyl groups. Phenolic compounds have the ability to act as antioxidants also by virtue of their capacity to inhibit some enzymes involved in radical generation, such as various cytochrome $\mathrm{P} 450$ isoforms, lipoxygenases, cyclooxygenase and xanthine oxidase ${ }^{24}$. The total phenol content was $213.22 \pm 0.36 \mu \mathrm{g} / \mathrm{mg}$ of GAE and the total flavonoid content was $28.95 \pm 0.21 \mu \mathrm{g} / \mathrm{mg}$ of QE in the extract (Graph 4). These results provide a comprehensive profile of the antioxidant activity of ripe fruits of ethanol extract of Prunus cerasifera with respect to their phenols and flavonoids content.

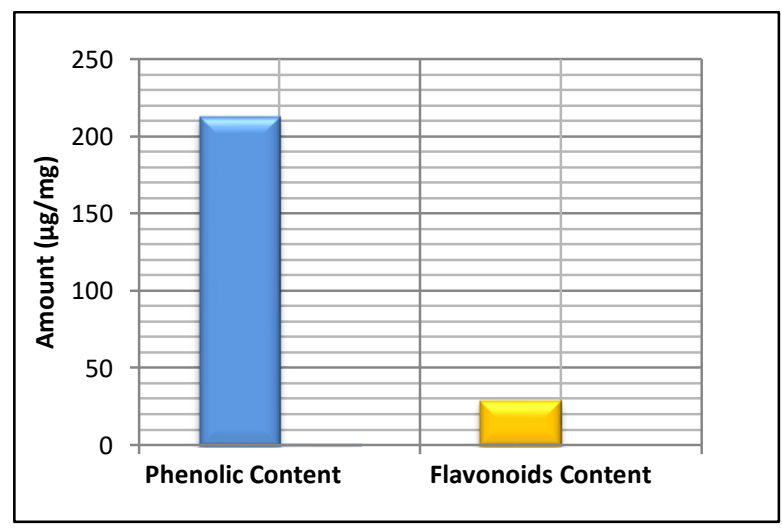

Graph 4: Determination of total phenols and flavonoids content of ripe fruits of ethanol extract of Prunus cerasifera

\section{Antibacterial activity by Agar well diffusion method}

The ripe fruits of ethanol extract of Prunus cerasifera were investigated for in vitro antibacterial activity against microorganisms including Gram-positive bacteria (Staphylococcus aureus, Bacillus subtilis) and Gram-negative bacteria (Proteus vulgaris, Escherichia coli). The antibacterial sensitivity of the ripe fruits of ethanol extract of Prunus cerasifera and their potency were assessed quantitatively by measuring the inhibitory zone around the wells in the petriplates (Table 4).

Table 4: Antibacterial activity of ripe fruits of ethanol extract of Prunus cerasifera

\begin{tabular}{|c|c|c|c|c|c|}
\hline \multirow[b]{2}{*}{ S.No } & \multirow[b]{2}{*}{ Bacterial pathogens } & \multicolumn{4}{|c|}{ Zone of inhibition (mm) } \\
\hline & & $\begin{array}{c}\text { Standard } \\
\text { Tetracycline }-\mathbf{3 0} \mu \mathrm{g}\end{array}$ & $\begin{array}{c}250 \\
\mu \mathrm{g} / \mathrm{mL}\end{array}$ & $\begin{array}{c}375 \\
\mu \mathrm{g} / \mathrm{mL}\end{array}$ & $\begin{array}{c}500 \\
\mu \mathrm{g} / \mathrm{mL}\end{array}$ \\
\hline 1 & Staphylococcus aureus & 27 & 15 & 16 & 17 \\
\hline 2 & Bacillus subtilis & 12 & 17 & 19 & 20 \\
\hline 3 & Proteus vulgaris & 11 & 14 & 17 & 18 \\
\hline 4 & Escherichia coli & 29 & 17 & 18 & 19 \\
\hline
\end{tabular}

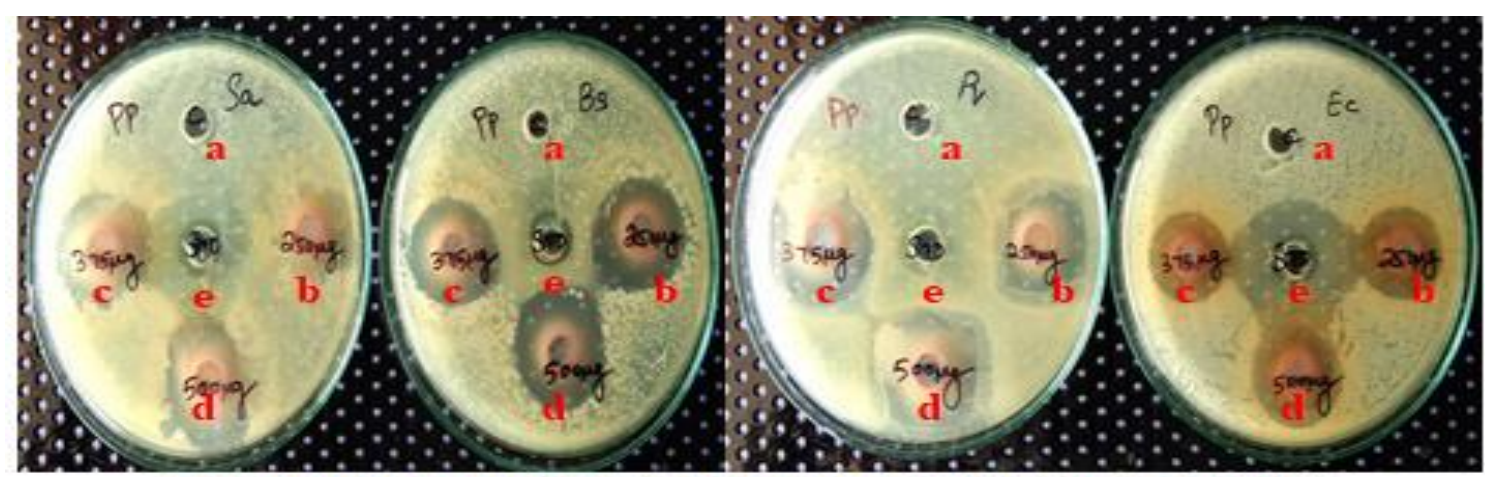

Concentration range of ripe fruits of ethanol extract of Prunus cerasifera: a-Solvent Control-Ethanol b-250 $\mu \mathrm{g} / \mathrm{mL}, \mathrm{c}-375 \mu \mathrm{g} / \mathrm{mL}$, d-500 $\mu \mathrm{g} / \mathrm{mL}$ e-30 $\mu \mathrm{g} / \mathrm{mL}-$ Standard (Tetracycline)

Figure 2: Antibacterial activity of ripe fruits of ethanol extract of Prunus cerasifera 
The maximum inhibitory effect for ripe fruits of ethanol extract of Prunus cerasifera against Bacillus subtilis was 20 $\mathrm{mm}$ at $500 \mu \mathrm{g} / \mathrm{mL}$ concentration and minimum inhibitory effect against Staphylococcus aureus was $17 \mathrm{~mm}$ at 500 $\mu \mathrm{g} / \mathrm{mL}$ concentration respectively (Figure 2). The antibacterial activity of the ripe fruits of ethanol extract of Prunus cerasifera could be correlated as due to the presence of secondary metabolites such as flavonoids, phenolic compounds, terpenoids, tannins and alkaloids that adversely affect the growth and metabolism of microbes.

Tannins bind to proline rich proteins and interfere with the protein synthesis ${ }^{25}$. Flavonoids are hydroxylated phenolic substance known to be synthesized by plants in response to microbial infection and it should not be surprising that they have been found in vitro to be effective antimicrobial substances against a wide array of microorganisms. Their activity is probably due to their ability to complex with extracellular and soluble proteins and to complex with bacterial cell walls 26 . Coumarins are also known act against gram positive bacteria and it is produced in carrots in response to fungal infection which could be attributed to its antimicrobial activity ${ }^{27}$. Antimicrobial property of saponin is due to its ability to cause leakage of proteins and certain enzymes from the cell ${ }^{28}$. Steroids have been reported to have antibacterial properties, the correlation between membrane lipids and sensitivity for steroidal compound indicates the mechanism in which steroids specifically associate with membrane lipid and exerts its action by causing leakages from liposomes 29 .

\section{CONCLUSION}

In human nutrition, fruits play an important role for balanced diet. They provide not only energy and also packed with vital protective nutrients. Comparatively fruits are the cheapest source of nutritive food which helps in building resistant against diseases. Sustainable development in health and education is imperative if human resources are to be protected and promoted for optimal performance. The results of the present study provides promising guidelines proving that plum fruits to be the richest source of antioxidant and antimicrobial properties. Hence, the pharmacological mechanism of plums considering at molecular level shall be evaluated for converting into an active drug for treating several diseases.

\section{ACKNOWLEDGEMENT}

The authors are thankful to Armats Biotek Training and Research Institute for providing facilities to carry out research work.

\section{REFERENCES}

1. Birwal P, Deshmukh G, Saurabh SP and Pragati S. Plums: A Brief Introduction: Journal of Food, Nutrition and Population Health, iMedPub Journals, 2017; 1:1: 8.

2. Stacewicz SM, Bowen PE, Husssain EA, Damayanti WBI Farnsworth NR. Chemical composition and potential health effects of Prunes: A functional food. Critical reviews in food science and nutrition, 2000; 41:251-286.

3. Heredia A, Barrera C, Andres A. Drying of cherry tomato by a combination of different dehydration techniques. Comparison of kinetics and other related properties. Journal of Food Engineering, 2007; 80:111-118.

4. Potter D, Eriksson T, Evans RC, Oh S, Smedmark JEE. Phylogeny and classification of Rosaceae. Plant systematics and evolution,2007; 266: 5-43.

5. Ertekina C, Gozlekcib S, Kabasa O, Sonmezc S, Akinci I. Some physical, pomological and nutritional properties of two plum (Prunus domestica L.) cultivars. Journal of Food Engineering, 2006; 75: 508-514.
6. Nakatani N, Kayano S, Kikuzaki H, Sumino K, Katagiri K. Identification, quantitative determination and anti-oxidative activities of chlorogenic acid isomers in prune (Prunus domestica L.) Journal of Agricultural and Food Chemistry, 2000; 48:5512-5516.

7. Abheri Das Sarma, Anisur Rahaman Mallick and Ghosh AK. Free Radicals and Their Role in Different Clinical Conditions: An Overview. International Journal of Pharma Sciences and Research, 2010; 1(3): 185-192.

8. Harborne JB. Phytochemical Methods, A guide to Modern Techniques of Plant analysis, second ed. Chapman and Hall, London, 1998; 54-84.

9. Raaman N. Phytochemical techniques. New India Publishing Agency, New Delhi, 2006; 306.

10. Khalaf NA, Shakya AK, Al-othman A, El-agbar Z, Farah H. Antioxidant activity of some common plant. Turk J Biol, 2008; 32:51-5.

11. Lokesh Deb SK, Dubey, Avijeet Jain, Amit Kumar Jain, Pandian GS. Free radical scavenging activity of aqueous n- butanol fraction of Prunus Persica aqueous extract. Journal of Natural Remedies, 2009; 9(2); 152-158.

12. Arnao MB, Cano A, Acosta M. The hydrophilic and lipophilic contribution to total antioxidant activity. Food Chem, 2001; 73:239-44.

13. Prieto $\mathrm{P}$, Pineda M, Aguilar $\mathrm{M}$. Spectrophotometric quantitation of antioxidant capacity through the formation of a phosphomolybdenum complex: specific application to the determination of vitamin E. Analytical Biochemistry, 1999; 269: 337-341.

14. Oyaizu M. Studies on products of browning reaction: antioxidative activities of products of browning reaction prepared from glucosamine. Jpn. J. Nutr, 1986; 44: 307315.

15. Spanos GA, and Wrosltad RE, Influence of processing and storage on the phenolic composition of Thompson seedless grape juice, Journal of Agricultural \& Food Chemistry, 1990, 38, 1565-1571.

16. Liu X, Dong M, Chen X, Jiang M, Lv X and Yan G, Antioxidant activity and phenolics of endophytic Xylaria sp. from Ginkgo biloba, Food Chemistry, 2007, 105, 548-554.

17. Eloff JN. Which extractant should be used for the screening and isolation of antimicrobial components from plants J. Ethnopharmacol, 1998; 60: 1-8.

18. Awika M, Rooney LW, Wu X, Prior RL. Cisneros Zevallos L. Screening methods to measure antioxidant activity of Sorghum (Sorghum ialmatei) and Sorghum product. Journal of Agricultural and Food Chemistry, 2003; 51:6657-62.

19. Wickens AP. Aging and the free radical theory, Respiratory Physiology, 2001; 128:379-391.

20. Miller DD. Mineral. In: Fennema, O.R. (Ed.), Food Chemistry, 1996; Marcel Deckker, New York, 618-649.

21. Yildirim A, Mavi A, Kara AA. Determination of antioxidant and antimicrobial activities of Rumex crispus L. extracts. J. Agric. Food Chem, 2001; 49:4083-4089.

22. Stadtman ER. Metal ion-catalyzed oxidation of proteins: Biochemical mechanism and biological consequences. Free Radical Biology and Medicine, 1990; 9:315-325.

23. Kim D, Jeond S, Lee C. Antioxidant capacity of phenolic phytochemicals from various cultivars of plums. Food Chem, 2003; 81: 321-326.

24. Tian Y, Jiang B, An L, Bao Y. Neuroprotective effect of catalpol against MPP+-induced oxidative stress in mesencephalic neurons. European Journal of Pharmacology, 2007; 568, 142148.

25. Shimada T. Salivary proteins as a defense against dietary tannins. J. Chem. Ecol, 2006; 32 (6): 1149-1163.

26. Marjorie C.Plant Products as Antimicrobial Agents. Clinical Microbiology Reviews, 1999; 12: 564-582.

27. Hoult JRS and Paya M. Pharmacological and biochemical actions of simple coumarins: natural products with therapeutic potential. Gen. Pharmacol, 1996; 27: 713-722.

28. Zablotowicz RM, Hoagland RE, Wagner SC. Effect of saponins on the growth and activity of rhizosphere bacteria. Adv Exp Med Biol, 1996; 405:83-95.

29. Raquel F. Epand, Bacterial lipid composition and the antimicrobial efficacy of cationic steroid compounds. Biochimica et Biophysica Acta, 2007; 2500-2509. 